\title{
Janjaweed, New Settlers and the Land Tenure: Do They Constitute an Obstacle to Peace in Sudan?
}

\author{
Dr. Anwar Yousif Ataelmanan Mohamed* \\ (PhD of Social Sciences), Sudanese Studies Centre, College of International Studies, Yangzhou University, \\ P.R.C. Faculty of Management Sciences and Economics, Al-Butana University, Rufaa, Sudan.
}

*Corresponding Author: Dr. Anwar Yousif Ataelmanan Mohamed, (PhD of Social Sciences), Sudanese Studies Centre, College of International Studies, Yangzhou University, P.R.C. Faculty of Management Sciences and Economics, Al-Butana University, Rufaa, Sudan.

\begin{abstract}
This research paper focused on the issue of land tenure and Hawakir, as it is the central issue in Darfur, and its various intersections, putting in consideration that, all the peace agreements concluded in Darfur, in various eras and governments, did not give this recital in the Darfur crisis the due attention and importance.
\end{abstract}

The paper examines the historical dimensions of land tenure in Darfur, since the establishment of the Sultanate of Darfur five hundred years ago, and the developments in the laws and traditional civil norms that have been regulating the process of land tenure in Darfur.

The paper presented to Al-Hawakir and its origins, the role it played in shaping the social and economic formation at that time, and feudal differentiation. The paper also examined the conditions caused by the deterioration in the natural environment, climate change and its impact on the diminishing of natural resources, such as water and pastures, and its role in bloody conflicts, between stable and pastoral tribes, in order to win pastures and water sources, which has evolved into political and demand dimensions, in the form of armed liberation movements, which have resulted in camps for the displaced in different parts of Darfur, and Darfurian refugee camps outside Sudan.

The paper also presented the topic of the new settlers, who came from outside Darfur. The paper the paper touched the land law in Sudan and the need to develop it.

The paper dealt with developments in the situation in Darfur after the December 19, 2019 revolution, and the impact of these developments on the issue of land ownership, tribal homes, and the issue of new settlers in light of the Juba Peace Agreement in Sudan.

The paper also alerted the need to address the issue of land tenure through a comprehensive peace conference in Sudan.

The researcher conducted a questionnaire containing 200 samples, randomly selected from the geographical field of research, and covering different ages, gender, educational levels and professions who directly participated in or witnessed the conflicts. The method of social statistical analysis was used to reach the results discussed and extracted recommendations and proposals to contribute to illuminations in the way of tackling the problem.

Key words: Tribe, Hawakir, Darfur crisis, Tribal areas, Darfur Sultanate, New settlers, Janjaweed (Quick Support Force).

\section{INTRODUCTION}

Land tenure and governance in Darfur have been a concern of the rulers and ruled throughout the history of the Sultanate of Darfur, which lasted for more than five hundred years, where the interest of most of the sultans who ruled the Sultanate of Darfur, who have made an effort to regulate the acquisition and distribution of land, and to take this as a means to control the Sultanate and ensure Social and economic security.

Throughout the pre-Islamic period in Sudan, the problems of inter-tribal conflict were limited to historical conflicts, political or administrative interventions by governments to create their own tribal loyalties, or problems of displacement due to drought and desertification, as well as regional and international conflicts, as well as because of the strategic location of Darfur, and its natural resources 
The conflict in Darfur has recently taken on new dimensions, instead of being confined to traditional tribal disputes over land and natural resources, and was seasonal in most of its cases, now armed movements of political and regional nature, have emerged and all have taken the slogans to address the issues of marginalization and lack of development as a cause of war, declared against the Khartoum government.

The situation was further complicated by the government's recourse to give a racist stance to the conflict by mobilizing Arab tribes, known as Janjaweed militias, supporting and arming them against non-Arab tribes. This has created a major rift in the unity and cohesion of Darfur society, in addition to the government resorting to the recruitment of new settlers from Arab tribes in North Africa and sub-Saharan Africa, to settle them in areas from which non-Arab tribes were expelled, mostly in the Fur areas, who were displaced to camps for displaced persons or sought refuge in neighboring countries. For fear of the scorched-earth policy, he practiced against them by the Janjaweed to vacate the land for the new settlers.

In fact, all the peace agreements signed between the government and the armed Darfurian movements, after the big explosion in April 2003, and the escalation of the crisis in Darfur, these agreements, did not pay enough attention to the issue of land tenure and Hawakir, and did not care or pay attention to the changes that have occurred in the norms of land tenure Interrelationships between the tribes of Darfur, the complexities of climate change, drought and desertification, diminishing arable and grazing land, and the apparent increase in population and livestock, as well as new settlers. This has produced a more complex reality than before.

Thus, the issue of land tenure and Hawakir in Darfur stands out as the Achilles heel in the story of the ancient Greek proverb, and the strategic question arises: will the new settlers take over the land and the Hawakir in Darfur and refuse to leave it to return to their original owners, will be the straw that will break the back of the camel, and lead the region to reproduce the conflict in Darfur, more violent and harsh, and turns into an open conflict, over land ownership and tribal areas, rather than a conflict over land resources?

\section{Definition OF The MaIn CONCEPTS}

\subsection{Hawakir:}

The word Hawakir is taken from Hakoura which means a piece of land, given by the Sultan to a small tribe within the area of a large tribe or a clan from any tribe, group or family or individual. In terms of boundaries, the boundaries of Hawakir are well known due to the clear sorting in the boundaries.

\subsection{Tribal areas:}

(Areas) means several well-known areas in Darfur, such as the Zaghawa tribe areas, the Masalit tribe areas, the Rizeigat tribe areas, and the Alberti tribe areas. The word (Areas) here does not mean possession of land but rather it is related to administration only, and British colonialism benefited from this system by creating a tribal federation. It includes many tribes in one administration, and the region is usually called by the name of the largest tribe in the specific geographical area, this is the reference on which these designations are based.

\subsection{New settlers:}

They are the Arab tribes that have recently arrived from some neighboring countries, and they have been settled in the lands of non-Arab tribes in North and Central Darfur. And where ownership of the land means, the residents have the right to it, and then the traditional civil administration, made up from the tribes of the region governs that land historically. Those who do not have the land belong to or are governed by the rulers of the landowners, and problems arise if they refuse to accept their judgment.

However, those who do not own land in Darfur have the right to benefit from the land resources, whether by grazing, hunting, or logging according to the established customs and traditions.

\subsection{Tribe:}

In this research paper, we mean an ethnic group that lives in a specific geographical area and is characterized by a social, political and judicial system and a common cultural heritage. Tribal groups in Darfur now constitute what looks like parallel institutions to modern civil society institutions and stand in the way of changing society's progress towards the institutions of the modern civil state. 
This corresponds to what was reported by Muhammad Al-Sobh ${ }^{(1)}$ who defined the tribe as "a group of tribes or human groups, and it has a dedicated land and common familiarity with its public and its villages, and also has one culture. Strong kinship and duties, Social solidarity prevails, and that these ties give them shared responsibilities, including the duties to defend their lands, their honor, their traditions, and their common beliefs.

\section{LITERATURE REVIEW}

In fact, the land tenure system and Hawakir sought to consolidate the sultanate's power, which lasted about 500 years, and was one of the functions created by the sultans to tighten their control over power and create the curse of the sultan and remained in continuous development from that period until it reached what it is now.

In his book The Fur and the Land, Abu Saleem stated that: ${ }^{(2)}$ "the status of the land in the Sultanate of Darfur was not defined, and that Sultan Musa (1715-1726) was the first one, who regulated the ownership of the land, and make all the land of the Sultanate his own land, and that private property is within this framework, then, every sheikh was acting in the territory of his tribe or his kingdom customarily"

Noam Choucair argued ${ }^{(3)}$ "Sultan Musa followed the famous ownership system in the east, with regard to the ownership of land, He made the whole country the property of the Sultan, and divided the urban country into Hawakir and fiefdoms, distributed it to his family and senior people, with sealed instruments, and made the sons of Sultans as leaders of the tribes and entrusted them to collect Zakat, as defined by Islamic law, this system continued throughout the reign of all the sultans who came after the Sultan Musa until the end of the rule of the Sultanate"

However, during the reign of Sultan Muhammad al-Husain (1839-1874), in an interview with Adam Tema, Mubarak al-Sharif reported: "Sultan Muhammad al-Husain worked hard to organize the land and distribute it to the tribes as their homes instead of being the property of the Sultan.

It is Sultan Mohammed al-Hussein who organized Darfur geographically, in order to avoid friction between farmers and pastoralists, in the land and pasture, he cruised on all borders of Darfur, and identified Hakoura for each tribe, and spent in this work for nearly seven years, until he was able to organize Darfur. Hakoura is granted to one tribe by its borders with neighbors from other tribes. Within Hakoura, the tribes homes is granted to minority tribes belonging to the main tribe of Hakoura, headed by the tribe leader, who is entrusted with the organization of farms, pastures and water fountains, and has the right to grant and prevent. These leaders have powers, to avoid friction between pastoralists and farmers. ${ }^{(4)}$

Hakoura is an Arabic word and pluralized on Hawakir, in the language of the Fur tribe it matched the word - RO and the plural is (ROTA) - ROTA.(5)

Who gives the Hakoura? It is the Sultan alone, and there is no right to give from others unless he agrees, followed by issuing a document from the Sultan, written in a special manner, in which he records the limits of Hakoura, its nature and its advantages.

" In other words, Hakoura means (agricultural, pastoral, residential, etc.), Which is given by a Sultan of the Sultanate of the Fur, to a person, group, tribe or clan by a royal decree, which defines its boundaries and belongs to them, and his family has the right to inherit them ${ }^{(6)}$

Hawakir is divided into four types: ${ }^{(7)}$

1. Hawakir, which was usually given to the poor, women of the royal family and the children of the sultans.

\footnotetext{
1 Muhammad Al-Sobh: The concept of the tribe in the third global theory, second edition, Cairo, 1990, p. 28.

${ }^{2}$ Muhammad Ibrahim Abu Saleem: The Fur and the Earth (ownership documents), the pamphlet (10), Institute of African and Asian Studies, University of Khartoum, 1975, p. 53.

${ }^{3}$ Naoum Choucair: Geography and History of Sudan, Part One, Beirut, 1967, p. 472.

${ }^{4}$ Dr. Mubarak Al-Sharif: Land ownership and Hawakir in Dar Four, paper presented for the Peace building Workshop, Center for Western Sudan Studies, Nyala, 2005, p. 6.

${ }^{5}$ Dr. M. Abu Saleem: Ibid, P 63.

${ }^{6}$ Ali Ahmad Haqqar: The Political Dimension of Tribal Conflict in Darfur, published MA thesis, Omdurman

Islamic University, Sudan Press Printing Company, 2003, p. 163.

${ }^{7}$ Dr. M. Abu Saleem: Ibid, P 71.
} 
2 - Regular Hawakir, it is usually for the campaign titles and court officials.

3 - The third type was to give the Sultan ownership rights over a number of villages in favor of some poor people in order to revive the fire of the Koran.

4- The fourth type Bedouin Hawakir.

"In the period of English colonialism, a great administrative effort was made to identify Darfur in terms of land and people, so as to manage and control it easily," said Teckna ${ }^{(8)}$.

They turned to the topographic and demographic study of Darfur, and carried out extensive surveys to develop detailed maps that depend on them in the future. In 1922, they were able to draw a complete map of Darfur, which established in its very precise details the borders of Darfur, in which Darfur was administratively divided into centers with administrative, security and judicial powers.

Each center was divided into smaller administrations in the form of tribal civil administrations based on established tribal boundaries, but with minor changes as required by administrative necessity ${ }^{(9)}$ however, the situation in these monuments did not continue as wished by those who enacted it or those who secured it in the period of British colonialism and the national governments that came after it. Arable land and the large increase in population and livestock, which made the need for the land in the opposite direction with the available areas suitable for agriculture and grazing, this has made the traditional conflict between the tribes in Darfur takes political dimensions with tribal demands On the subject of land ownership.

Al-Tijani Mustafa goes in the same direction and stresses that ${ }^{(10)}$ "peaceful coexistence between the tribes of Darfur prevailed in the region, and that relations are governed by customs and traditions, along with ethics of tolerant Islam, and Darfur was closely linked, in terms of social, economic and development in Sudan's large society.

All of this has contributed to the linkage and survival of the social fabric of Darfur strong and has positive indicators, but the situation is now very different from what was before, and the ownership of land and tribal homes today is one of the most important causes of tribal conflict in Sudan, especially Darfur.

In order to search for a proper approach to understanding the problem of land ownership and Hawakir, and the resulting problems and tribal conflicts, we must not rely too much on the historical approach, and that Hawakir and tribal homes have become an integral part of the heritage of the people of Sudan, and became historical rights, and have serious political dimensions, It should therefore be covered by politicians, administrators and planners with much scrutiny before deciding on it".

Ownership of land and natural resources is of paramount importance in the process of stability and development throughout the Sudan. The Comprehensive Peace Agreement between the Government of the Republic of the Sudan and the Sudan People's Liberation Movement (SPLM) has devoted considerable space to it. ${ }^{(11)}$

Chapter III (Wealth Sharing) provides a detailed description of how to deal with the ownership of land and natural resources, through the establishment of a national land commission whose task is to regulate land ownership and how to use natural resources on the surface and in the interior.

With regard to the specificity of Darfur in relation to the issue of land ownership, the Abuja Declaration of July,5 2005 focused on this issue, stating that ${ }^{(12)}$ : "in the interest of sustainable development, the problems of environmental degradation, water resources and land use must be resolved. The traditional mechanisms governing land ownership in Darfur must also be taken into account in accordance with the provisions of the National Constitution."

\footnotetext{
${ }^{8}$ Atta Al-Mannan and others, Report on Tribal Conflict in Darfur, Workshop on Security Arrangements after the Abuja Agreement, University of Nyala, October 2006.

${ }^{9}$ Youssef Tekneh: Report on Tribal Conflict in Darfur, working paper presented at the Conference on Security and Peaceful Coexistence in Darfur, 1997, p. 46.

${ }^{10}$ Dr. Al-Tijani Mustafa Mohamed Saleh: Causes of Tribal Conflict in Sudan, a scientific paper presented at a symposium (Insights on Tribal Conflicts in Sudan), Institute of African and Asian Studies, University of Khartoum, 1998, p. 13.

${ }^{11}$ The Sudanese Comprehensive Peace Agreement, Chapter Three, Item Two (Land Ownership and Natural Resources), pp. 54-57.

${ }^{12}$ Declaration of Principles on the Darfur Conflict, Paragraph 12, Abuja, Nigeria, July, 52005.
} 
As the Darfur Peace Agreement states in Chapter II $\left.{ }^{(13}\right)$ : “it is important to recognize traditional and customary rights, including monuments and historical land rights, on a sound and sustainable basis to ensure the means of subsistence and development of Darfur. To recognize and protect those rights. The Parties agree to establish a mechanism that defines the processes for ensuring the sustainable use and control of land and other natural resources, to ensure that all citizens affected by land development and / or natural resource exploitation are consulted and their views taken into account in the implementation of this development process. As a result of land and / or natural resource development, they are entitled to adequate compensation.

Land management structures and institutions are developed and legally supported to promote sustainable development and address environmental degradation problems.

The issue of land and natural resources, because of its importance and sensitivity, was included in the agenda of the (Darfuri-Darfuri) dialogue that emerged from the Darfur Peace Agreement to be deliberated and consulted on because of its significant impact on security, stability and development in Darfur in paragraph 483 / b / p. 101. Land, water and natural resources and the location and organization of Bedouin roads. $\left({ }^{14}\right)$

The sustainability of land is a very important process for achieving sustainable development, anywhere, because land is the central asset, and the main element in the process of urbanization in its various dimensions, especially social ones, because it is the first step to invent livelihoods, and as a center for development and accumulation of wealth for the benefit of current generations, without neglecting the right of future generations.

There is a significant weakness in the participation of local communities in the land use planning process, as the way land is used in the community is of paramount importance, and requires inevitable measures to regulate ownership. It is the process of rationing and a thoughtful insight into what is the best use.

The legalization of land ownership is important for creating planned and effective development, and greatly facilitates financing, financial lending and investment.

Land is the key asset for the rural poor not only for social and economic development but also for enabling them to stabilize and rebuild their areas, thereby reducing the increasing rural exodus of cities, arguably one of the most important actors in the fight against poverty.

Through increased attention to land ownership and how to use its resources in all recent peace agreements in Sudan (Abuja Declaration, Naivasha, and DPA), ownership of land and tribal areas, especially in Darfur, is one of the most important, if not central issues.

We say that, in light of the steady increase of population and livestock, offset by the continuous decrease in the arable areas and grazing, and the lack of water resources, as a result of the continuous environmental degradation, which created an imbalance, led to spontaneous conflict between the population over who is entitled to use the remaining fertilized land for agriculture or grazing, this was caused by the complete absence of deliberate scientific planning for the sustainability of the land, That turned the conflict into an all-out war, destroyed the green and solid land of Darfur, and destroyed all infrastructure, despite the lack and weakness, and transformed Darfur from the field of need for development and building on what exists, to start from scratch, especially in the countryside.

This is evident from the scale of the devastation of the rural Darfur war, which has also extended to the psychological, economic and social effects of the region, which have affected the entire community, including:

1. The countryside was almost completely destroyed, including the wealth, buildings, and means of production, services and water resources.

More than two million citizens have become refugees, thousands have died.

2 - The effects of the war put great pressure on the psychological stability of the human being in Darfur, the loss of parents and child, death or separation and the life of displacement, oppression, and lack of security and fear of the unknown.

\footnotetext{
${ }^{13}$ Darfur Peace Agreement: Chapter Two, Wealth Sharing, Article 17, General Concepts and Principles of Wealth Sharing, Wealth Sharing Principles, Paragraphs 110/111/112, pp. 29/30

${ }^{14}$ (Darfuri-Darfuri) dialogue The issue of land and natural, stability and development in Darfur in paragraph 483

/ b / p. 101. Land, water and natural resources and the location and organization of Bedouin roads.
} 
The effects of this are evident in the IDP camps, from psychological and mental dysfunction, bitter memories and retaliation.

3 - There are other effects of the war did not exclude Darfur, including the widespread unemployment and the spread of drugs, especially among young people in addition to making Darfur one of the corridors of the drug trade from West Africa and a large market for illegal arms trade, in addition to all the other temptations of the war, such as looting theft and moral deviations and others.

4. The extensive destruction of the natural environment, the deterioration of environmental health and water pollution. $\left({ }^{15}\right)$

Eric Reeves says in his testimonies in a report entitled Demographic Change presented to the United Nations: "The quantitative estimate that exists here of violent land dispossession - and increasingly by Arab groups from outside Sudan - is unprecedented. My hope is that the importance of this issue becomes clear," To expose the enormous obstacle that this land grab has created for any meaningful peace process in Darfur, and it continues to be dealt with unaddressed in any negotiation process. "( $\left.{ }^{16}\right)$

\section{DeVElopment AND LAND TENURE}

If we look at land ownership in the states of Darfur, we find that the link between man and land in terms of livelihoods and the subject of work is the common denominator, and there is only a difference in the customary ways of organizing land ownership and the inherent customs and traditions and the circumstances of its historical development.

In Darfur, many elements have caused land ownership and access to resources to be one of the central issues that led to the current crisis.

1. Environmental degradation and climate change that have led to drought, desertification, lack of rainfall and shrinking agricultural lands and pastures.

2. The intensification of competition for these declining resources is also offset by the increase in population and livestock and the increasing need for food and pasture.

The forced displacement of some tribes due to drought, desertification, encroachment and occupation of Hawakir owned by other tribes, has led to the escalation of the conflict over land ownership and the priority of the right to use it.

In addition, the traditional struggle between pastoralists and farmers over access to land uses.

The Earth and its natural resources are the primary stage of human activity throughout the ages. It is also the subject of human strength and weakness, misery and happiness, a source of elevation, degeneration and sometimes humiliation, because the conflict revolves around it, and competes for its areas, resources and locations throughout history, among peoples, at the global, regional and local level.

Because of the land, empires thrived, empires faded, and civilizations and peoples advanced and nations competed.

The land with its resources is the backbone of development and the most important pillars of the failure or success of development.

Agriculture is the main means of subsistence for most of the world's population. In developing countries, the majority of the population lives in rural areas. Land is the sole asset of the population in the process of earning a living. Land shortage simply means extreme poverty. Human life is linked to land, hunger, satiety, social stability, progress, underdevelopment, environmental degradation, climate change and everything.

In Sudan, conflict over land and its resources has been one of the most important causes of tension between different population groups, especially between farmers and pastoralists and pastoralists themselves. This conflict is exacerbated by the dramatic deterioration in the value of the land and its resources and product due to erosion, drought, desertification and global climate change.

\footnotetext{
${ }^{15}$ Anwar Yousif \&Others, Socio-Psychological Impact of the Darfur War on Women and Children, Middle-East Journal of Scientific Research 19 (5): 697-701, 2014, ISSN 1990-9233, (C IDOSI Publications, 2014, DOI: 10.5829/idosi.mejsr.2014.19.5.21016.

16 , Eric Reeves, Author, Maya Baca, research and editing, Changing Demography, Violent Expropriation and Destruction of Farmlands in Darfur, Nov 2014-Nov 2015, report presented to UN.
} 
The land tenure in rural areas, especially in the peripheral states, has been and is traditionally not framed by the law. The British colonization in the organization of land ownership was based on the frameworks of Traditional civil administration.

Mohamed Omar Bashir, stated: "Land Settlement and Registration Act of 1925 stipulated that all unregistered land is owned by the government, and the Land Expropriation Act of 1930 empowered the Governor-General to seize any plot of land for public use.

Land laws have not in fact affected the traditional rights of individuals, tribes and groups to acquire land.. ${ }^{(17)}$

The Abuja Agreement for The Peace of Darfur in 2005, confirmed," The state recognized the rights of collective land, i.e. tribal land (Hawakir) in accordance with customs and traditions."

This was also confirmed by the Doha Document for the Peace of Darfur (2011), which became part of the Constitution of the Sudan, in Article 34: section $188^{(18)}$ "The rights of ownership of tribal lands (Hawakir), historical rights relating to land, traditional paths of livestock and access to water sources must be established and protected, All relevant levels of government must initiate and complete a development process to gradually amend the relevant laws to include customary laws. In accordance with international practices and attitudes in this regard. To protect the traditional heritage, the traditional and customary paths of livestock that have been closed, whenever possible, are reopened or other alternative routes open. Section 189: Laws on land amended in accordance with section (188), must provide for the recognition and protection of historical, traditional and customary land rights. Section 190: States that no person or group of persons may be deprived of any traditional or historical land rights, or their right to access water sources, without consulting them and compensating them fairly and urgently."

It also states: possession of land, which was carried out in bad faith, not protected by law:

Article 638 of the Civil Transactions Act 1984 recognizes the following:

"The possessor becomes ill-intentioned from the time he learns that possession is an assault on the right of others."

Article 2/638/2 of the same law decides the following: ${ }^{(19)}$

"The holder is considered bad faith from the time of his announcement in the newspaper of the case that possession is an attack on the right of others, as well as bad faith if he rapes possession under duress of others."

What was quoted above from the Abuja Peace Agreements 2005 and the Darfur Peace Agreement in Doha in 2011 is in line with the customary law in Darfur, which is the law on tribal hovercraft inherited from the Sultanate of Darfur and has not been changed after Darfur became part of Sudan in 1916, as it is contrary to the state's official law, with regard to land ownership and uses, whether it is the 1930 Act and the Civil Transactions Act of 1984, is required to make efforts to eliminate the conflict between customary law and official law.

In the period of national governments, a large part of the land for mechanized farming projects was widely distributed in the private sector, at the expense of local farmers and herders, to groups and individuals who are not residents of those areas, at the expense of forests and vegetation. This led to tension and conflict on the ground in these areas, which turned into a conflict between the government and the population, and the biggest manifestation was that some of the inhabitants of these areas took up arms against the government, within the components of the SPLM in the period from 1983-2005.

Population growth and the growing need for land under extremely complex natural conditions of environmental degradation, drought, and desertification and soil poverty have led to the inability of the local administration to control and regulate land ownership, especially in rural areas, in addition to the self-weakness of traditional civil administration, loss of prestige and power. Large segments of the population have emerged from their burdens and are more affiliated with the modern civil state,

\footnotetext{
${ }^{17}$.Muhammad Omar Bashir: History of the National Movement in Sudan, The Historical Roots of Modern Sudan, Second Edition, Dar Al-Jeel, Beirut, Lebanon, 1987..

${ }^{18}$ Section 188/190, Article 34, Darfur Peace Document, Doha, Qatar, 2011.

${ }^{19}$ Article 638/1/2, Civil Transactions Act, Ministry of Justice, Khartoum, Sudan, 1984
} 
especially the educated sectors who believe that history has bypassed traditional civil administration and the influence of tribal leaders, due to education, awareness-raising and openness.

After Naivasha, the National Land Commission was established to address the problem of land ownership in the south and the three regions (Abyei, Nuba Mountains and Blue Nile). Due to the specificity and sensitivity of the issue of land ownership in Darfur and its importance, the DPA postponed the discussion of the issue until a special commission is established in the future.

The ownership and use of land was not strongly present in the minds of those responsible for development planning in Sudan, nor did the land occupy a strategic space in terms of quantitative and qualitative use in the imagination of those who planned development projects in Sudan.

Land ownership in Darfur is subject to the traditional system, with the exception of cities and some government holdings such as army camps and government projects. Ownership for personal or family benefit for the purpose of housing, stable rain-fed agriculture or irrigation shall be within the limits of exploitation.

This is not far from the situation in rural Africa in general and West Africa in particular, where the relationship between man and land is similar in terms of the way of ownership and use, because the land is the subject of life and everyone or family has the right to own a piece of land for agriculture or use of land for grazing, it also has the right to freedom of hunting and access to forest products.

If a person acquires an empty piece of land and uses it for construction or agriculture, it gives him the right to own it, according to the prevailing customs and traditions.

The utilization of the land and its resources and the regulation of its use are always governed by several elements: The general strategy of the State in its various sectors of agricultural, industrial, services and others, including the production of food, cash crops, industrial projects, roads, transportation and housing. The expansion of agriculture at the expense of pastures, in addition to the continuous change in climate, accompanied by drought and desertification and the large increase in livestock and the inability of the land to meet the needs of these variables and overgrazing operations and the destruction of farms, all these things cause conflicts and wars.

All the above-mentioned elements have been controlling the utilization of the land and its resources. Throughout the ages, the land and its resources have been at the center of the conflict. Pride, great social value, signification of wealth, prestige, power, greatness and status of the tribe. The conflict in Darfur, especially in the recent period, has taken on deep strategic dimensions among the tribes. Despite the emergence of political armed movements, it is concentrated around rich land, capable of production, and water resources.

\section{MeTHOdOLOGY}

In fact, what has happened and is happening in Darfur is in fact, conflict over land as it represents life in all its components.

So the strategic question in this paper was:

Do you agree that, the central issue in Darfur crisis was the land tenure?

Seven hypotheses emerged from which the respondents answered according to the options presented to them in the tables and analysis below:

\subsection{Population and Study Sample}

The study population means the total set of elements through which the researcher seeks to disseminate the results related to the problem studied. The original study population consists of all residents of Darfur.

The study sample was randomly selected from the study population, where the researcher distributed (200) questionnaires to the targeted.

In order to come up with as accurate results as possible, the researcher was keen on the diversity of the sample of the study in terms of including the following:

Individuals of both sexes 
2 - Individuals of different age groups

3. Individuals of different academic qualifications

4. Individuals from different tribes (Fur, Brno, Zaghawa, Tamah, Barqou, Daju, Habbaniyah, Maslamiya, Hawara, Masalit, etc.).

5. Individuals from various professional positions (managers, doctors, human rights activist, political activist, teachers, tribal leaders, lawyers, students, farmers, policemen, merchants, IDPs).

6. Foreign aid workers (20 persons)

7. IDPs in Kalma camps in South Darfur, Hasahayisa in West Darfur and Abu Shouk in North Darfur (an average of 30 IDPs from each camp)

8. Individuals of different marital status.

The questionnaire, consisting of one main question and seven hypothesis, was distributed to the selected sample of the study.

Data and information were emptied in tables prepared by the researcher for this purpose, where the nominal variables (strongly agree, agree, neutral, disagree, strongly disagree) were converted into quantitative variables $(1,2,3,4,5)$.

The main question: Do you agree that, the central issue in Darfur is land tenure? The Hypothesis \# 1: The conflict over the ownership of Hawakir and tribal areas is the central issue in Darfur.

Table1. Frequency distribution of the responses of the study sample to the first statement

\begin{tabular}{|l|l|l|}
\hline Answers & \# of answers & Percentage \% \\
\hline Strongly Disagree & 35 & 17.7 \\
\hline Disagree & 28 & 14.1 \\
\hline Neutral & 8 & 4.4 \\
\hline I agree & 55 & 27.8 \\
\hline I totally agree & 72 & 36.0 \\
\hline Total & 198 & 100 \\
\hline
\end{tabular}

Source: Researcher preparation from the field study, Excel, 2014

From the table above, the respondents' answers to the hypothesis show that the conflict over the ownership of Hawakir and the tribal homes is the main issue in Darfur. $63.8 \%$ agree with this and $31.8 \%$ disagree

The Hypothesis \#2: solving the problem of land and Hawakir and tribal areas paves the way for a final solution to the problem of Darfur.

Table2. Shows the frequency distribution of the responses of the study sample to the second statement

\begin{tabular}{|l|l|l|}
\hline Answers & \# of answers & Percentage \% \\
\hline Strongly Disagree & 34 & 17.2 \\
\hline Disagree & 26 & 13.1 \\
\hline Neutral & 4 & 2.0 \\
\hline I agree & 59 & 29.8 \\
\hline I totally agree & 75 & 37.9 \\
\hline Total & 198 & 100 \\
\hline
\end{tabular}

Source: Researcher preparation from the field study, Excel, 2014

The table shows the answers of the respondents to the hypothesis :solving the problem of land and Hawakir, and tribal areas paves the way for a final solution to the problem of Darfur, we find that $67.7 \%$ confirm the validity of the phrase, while $30.3 \%$ go to not true.

The Hypothesis \# 3: in all the agreements that have been signed to solve the problem of Darfur, we find the devil of details in the ownership of land and tribal areas.

Table3. Frequency distribution of the responses of the study sample to the first statement of the responses of the study sample to the third statement

\begin{tabular}{|l|l|l|}
\hline Answers & \# of answers & Percentage $\%$ \\
\hline Strongly Disagree & 17 & 8.6 \\
\hline Disagree & 35 & 17.7 \\
\hline
\end{tabular}


Janjaweed, New Settlers and the Land Tenure: Do They Constitute an Obstacle to Peace in Sudan?

\begin{tabular}{|l|l|l|}
\hline \multicolumn{2}{|l|}{} \\
\hline Neutral & 20 & 10.1 \\
\hline I agree & 58 & 29.3 \\
\hline I totally agree & 68 & 34.3 \\
\hline
\end{tabular}

Source: Researcher preparation from the field study, Excel, 2014

It is clear from the respondents' answers to the hypothesis: In all the agreements signed to resolve the Darfur problem, we find that Satan details in the ownership of land and tribal areas that $63.6 \%$ agree with their validity, while $26.3 \%$ disagree with it, and the evidence remains that it failed to dismantle the camps for the displaced and return them to the land from which they were displaced. Because of the new settlers brought by the government-backed Janjaweed forces.

The Hypothesis \# 4: there is no relationship between land ownership and prolonging the conflict in Darfur.

Table4. Frequency distribution of the responses of the study sample to the first statement of the responses of the study sample to the fourth statement

\begin{tabular}{|l|l|l|}
\hline Answers & \# of answers & Percentage \% \\
\hline Strongly Disagree & 72 & 36.3 \\
\hline Disagree & 46 & 23.2 \\
\hline Neutral & 14 & 7.0 \\
\hline I agree & 28 & 14.1 \\
\hline I totally agree & 38 & 19.4 \\
\hline Total & 198 & 100 \\
\hline
\end{tabular}

Source: Researcher preparation from the field study, Excel, 2014

From the table, the respondents' answers to the hypothesis indicate: There is no relation between land ownership and tribal areas and prolonging the conflict in Darfur, where $33.5 \%$ agree with the validity of the statement while $59.5 \%$ disagree.

The Hypothesis \# 5: solving the problem of ownership of land and tribal homes is not a priority or concern for the people of Darfur at present.

Table5. Frequency distribution of the responses of the study sample to the fifth statement.

\begin{tabular}{|l|l|l|}
\hline Answers & \# of answers & Percentage \% \\
\hline Strongly Disagree & 62 & 31.3 \\
\hline Disagree & 48 & 24.2 \\
\hline Neutral & 11 & 5.6 \\
\hline I agree & 42 & 21.2 \\
\hline I totally agree & 35 & 17.7 \\
\hline Total & 198 & 100 \\
\hline
\end{tabular}

Source: Researcher preparation from the field study, Excel, 2014

From the table, it is clear from the respondents' answers to the hypothesis: Solving the problem of land ownership and tribal homes is not a priority or concern for the people of Darfur at the moment, where $38.9 \%$ support the validity of the phrase while $55.5 \%$ do not support it.

The Hypothesis \# 6: the Doha Agreement concerned the ownership of land and tribal areas as an important issue in the Darfur crisis in a way that satisfied all parties.

Table6. Frequency distribution of the study sample responses to the sixth statement.

\begin{tabular}{|l|l|l|}
\hline Answers & \# of answers & Percentage \% \\
\hline Strongly Disagree & 73 & 36.9 \\
\hline Disagree & 53 & 26.8 \\
\hline Neutral & 16 & 8.1 \\
\hline I agree & 32 & 16.2 \\
\hline I totally agree & 24 & 12.1 \\
\hline Total & 198 & 100 \\
\hline
\end{tabular}

Source: Researcher preparation from the field study, Excel, 2014

It is clear from the respondents' answers to the hypothesis: The Doha Agreement concerned the ownership of land and tribal areas as an important issue in the Darfur crisis in a way that satisfied all parties, where $28.3 \%$ agree with the phrase while $63.7 \%$ oppose it. 
The Hypothesis \# 7: the evacuation of new settlers from the land of the displaced, and the disbanding of all militias of the armed movements, including the Janjaweed, the so-called (rapid support), is only a guarantee of the sustainability of peace and not reproduce the crisis.

Table7. Frequency distribution of the responses of the study sample to the seventh statement.

\begin{tabular}{|l|l|l|}
\hline Answers & \# of answers & Percentage \% \\
\hline Strongly Disagree & 28 & 14.3 \\
\hline Disagree & 22 & 11.2 \\
\hline Neutral & 8 & 4.3 \\
\hline I agree & 44 & 22.2 \\
\hline I totally agree & 96 & 48 \\
\hline Total & 198 & 100 \\
\hline
\end{tabular}

Source: Researcher preparation from the field study, Excel, 2014

It is clear from the respondents' answers to the hypothesis: the evacuation of the new settlers from the lands of the displaced, and the disbanding of all militias of the armed movements, including the Janjaweed, the so-called (rapid support), is the only guarantee for the sustainability of peace and not to reproduce the crisis.

$70.2 \%$ agree with the statement while $25.5 \%$ oppose it.

What is stated above, confirmed by the United Nations Security Council at its 5905th meeting in New York, where it recorded: (and the seizure of land is carried out on a regular basis. Sudanese officials do not facilitate the return of the displaced persons, but rather facilitate the settlement of groups affiliated to the Janjaweed militia to the land. The displaced people fear that new settlers will obtain land tenure rights, while they refuse to count in the Kalma, Carandge and Abazar camps, violence against the displaced, to compel them to accept the census, and besides the perpetrators of the impunity of the perpetrators of crime and its official denial, victims suffer as a result of this devastating psychological damage. ${ }^{(20)}$

Eyewitnesses support this, and a 27-year-old farmer named Faisal, said he saw "Janjaweed families come from the north with dozens of bags" in the first week of April. He added, "They arrived in Geneina and the government cars were behind them. From Geneina they moved by car south to Habila and Forbranga. Big cars in each of 30-40 people. I counted about 13 families. The Masalit house is turning into an Arab region. They will bring their families." When we asked him how he knew that these travellers were Arabs, he answered: "Why do you ask this question? Do you think we do not know? We know them from their colour, their language, and their clothes. They differ from us." ${ }^{(21)}$ Although the movement of families appears to be weak now, a number of IDPs reported that they saw Arab children and women in places where only armed men were present before. A twenty-second year's old farmer named Hassan said:

"He saw Arabs are with their families and children and a lot of cows" in the villages of Tor, Orum and Toulos. ${ }^{(22)}$

An old man from Tonfoka said that he saw several Arab families in Tonfoka when he recently returned to, at night to save some properties. He said that one of the families built a new house, not the traditional way of Masalit, while another family inhabited one of the unburned huts owned by a man named Abdul Majeed Fadel. He said that the Arabs built a new mosque in the village. When we asked him what the Arab women were doing, he answered, "They were collecting food and delivering it to the government that was collecting it in trucks."(23)

\footnotetext{
${ }^{20}$ Security Council, Sixty-third year, Session 5905 Thursday, 5 June 2008, 10 am New York.

${ }^{21}$ http://www.hrw.org/ar/report/2004/05/06/255586.

Interview held by Human Rights Watch, with a person named Faisal, an elderly farmer, The City of ElGeenaina, early 2004, report: Darfur destroyed, Genocide committed by the government and militia forces in western Sudan, Volume 16 A, May 2004.

${ }^{22} \mathrm{http}: / / \mathrm{www} . \mathrm{hrw} .0 \mathrm{rg} / \mathrm{ar} / \mathrm{report} / 2004 / 05 / 06 / 255586$.

Interview held by Human Rights Watch with a person named Hassan, a 22 years old farmer, Orum village, early 2004, report: Darfur destroyed, Genocide committed by the government and militia forces in western Sudan, Volume 16 A, May 2004.

${ }^{23}$ http://www.hrw.org/ar/report/2004/05/06/255586.
} 
There is also support and affirmation of the IDPs' adherence to regaining the land that was stolen from them by the new settlers as a condition for peace and their refusal to settle in areas other than their original homes.

On 30 September 2015, Radio Dabanga, $\left({ }^{24}\right)$ which specializes in news of the conflict in Darfur, which broadcasts its news from the Netherlands in Arabic, polled the opinions of the displaced about voluntary return, in accordance with the Doha Peace Agreement for Darfur: Residents of Kalma camp for the displaced rejected the state's declaration of housing projects for the displaced Those whose places of origin have been occupied by new settlers.

The governor intends to house the displaced in other areas. Yaqoub Muhammad Abdullah, the general coordinator of Darfur camps, told Radio Dabanga that in a meeting between Kalma camp leaders and Governor Adam El-Faki, the latter said that his government is seeking to implement a housing project at the camp site, similar to the camp that was planned in the neighboring Kass locality. "El-Faki intends to grant over 160,000 IDPs in Kalma camp around 3,000 housing plots in Kass, and after replanning Kalma camp itself, about 10,000 plots at the camp site.

The IDPs want to regain their lands, and they cannot understand why members of Arab militias, some from Chad, Niger and even Mali, are allowed to settle on these lands.

The year 2019 witnessed a qualitative development in the path of the Rapid Support Forces (Janjaweed), from the political point of view, this was represented in the participation in the Sudanese Transitional Military Council since April 2019, and from the constitutional point of view it was represented within the government forces in the constitutional document signed by the Military Council and the declaration of the forces of Freedom and change, but at the same time the Janjaweed forces have a separate military leadership, and this added a new complication to their anomalous and already complex situation, as it came to parallel the Sudanese Armed Forces.

The important documents related to the entitlements of the transitional period in Sudan following the revolution of December 19, 2019, on top of which is the constitutional document, which stipulated that a comprehensive peace conference have to be held in Sudan, and one of its most important core issues in Chapter Fifteen, Peace Issues, Article 68, G- Land and Hawakir issues ${ }^{(25)}$

In the Sudan Peace Agreement signed in Juba $\left({ }^{26}\right)$, the capital of South Sudan on Oct 3, 2020, between the Revolutionary Front and the government of the transitional period in Sudan, the Security Arrangements Agreement in Paragraph 9.12.1 made the Rapid Support Militia at the same level as the Sudanese Armed Forces. In fact, this situation completely contradicts the constitutional document that stipulates the dissolution of all militias and the formation of an army with a nationalist ideology before the end of the transitional period.

The peace negotiations with the Revolutionary Front in which the government delegation was headed by the commander of the Rapid Support Forces (Janjaweed), which are the forces responsible for expelling the non-Arab population from their lands and replacing them with new settlers, this also makes the scene on the ground more complicated, as the Rapid Support Militia has become an opponent and arbiter at the same time.

Moreover, the Sudan Peace Agreement signed in Juba, avoided in all its articles, and intended, not to address the issue of the new settlers or discuss it at any level.

\section{DISCUSSION}

Through the statistical analysis of the answers of the respondents to the hypothesis of "land ownership and tribal homes is the central issue in Darfur", we find the opinions of them, have come in

Interview held by Human Rights Watch with a person named Faisal, an old man, Tonfoka village, Dar Masalit, early 2004, report: Darfur destroyed, Genocide committed by the government and militia forces in western Sudan, Volume 16 A, May 2004.

${ }^{24}$ Radio Dabanga, Poll of IDPs' Views on Voluntary Return, According to the Doha Agreement for Peace in

Darfur: It broadcasts news from the Netherlands in Arabic, specializing in news of the conflict in Darfur, September 30, 2015, 09:45

${ }^{25}$ Interim Constitutional Document, Peace Issues, Chapter Fifteen, Article 68, G- Land and Hawakir issues. Khartoum, 17/08/2019.

${ }^{26}$ Sudan Peace Agreement, Security Arrangements, Paragraph 9.12.1 Juba, South Sudan, Oct 3, 2020 
accordance with the hypothesis, the issue of land ownership and tribal shrines is currently of paramount importance in Darfur. It is also at the centre of the case, and is considered a timed mine that can explode at any moment, unless, it addressed and given the utmost importance in any peace agreement if the operators want a sustainable peace.

Any dialogue that is currently being held on land tenure in Darfur should take the new changes in the issue of land tenure and the challenges facing the dialogue on this at all levels, especially at the community level, rather than at the national and regional level.

It is important that the land rights are clearly stipulated, and that land rights are specifically designed for the benefit of current generations and safeguard the rights of future generations. Especially since there are preparations at the end of the current transitional period after the revolution of 19 December 2019 to hold a constitutional conference through which a permanent constitution is formulated for Sudan, so any peace talks or peace conference may take place, the land issue and its uses, must be one of the main issues, which must be agreed upon, the development of the current land law, must take into account historical rights and urgent needs at the national level so that it takes into account the needs of development and peaceful coexistence and the planned use of resources for the benefit of society as a whole, and rationalize the use of resources and prevent monopoly, this was ignored in all previous peace agreement, this time we must have to reach a sustainable peace agreement.

The issue of new settlers remains a thorny issue that needs to be dealt with a high sense of national sovereignty and national security as a top priority by conducting an internationally supervised investigation of these settlers and returning them to the areas from which they came.

Land tenure and Hawakir in Darfur remains the main issue that can reproduce the conflict in Darfur in a new form, centred on the direct conflict over land tenure, and that will happen if the mentality of dealing with this issue is not changed. We must accompany changes in perceptions about the societal, political, and security situation, and to realize the growing collective awareness among people, and to deal with the root causes of the problem.

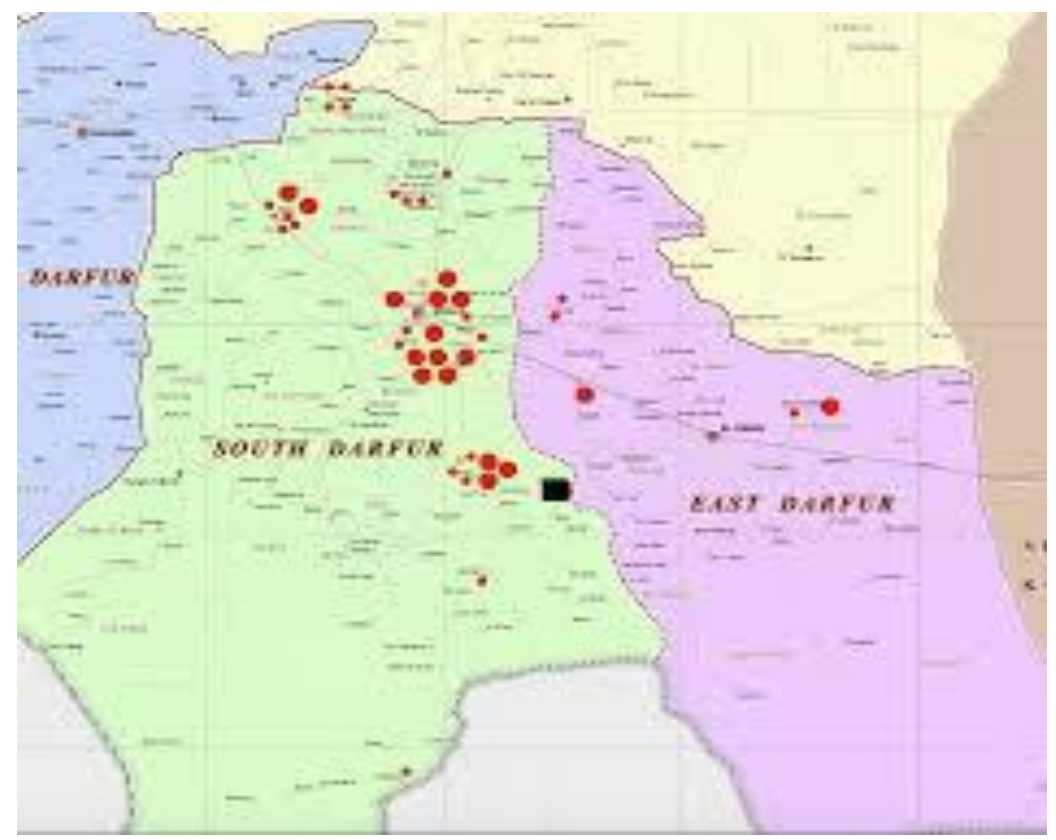

A map showing lands that were taken from the non-Arab tribes by the new settlers

\section{Source: United Nations Administration Maps in Darfur}

\section{CONCLUSION AND RECOMMENDATIONS}

Based on the foregoing, achieving sustainable peace and avoiding reproduction of war requires a new understanding that pave the way for solutions, which address the roots of the Darfur problem in a comprehensive manner, and this is done through:

1- Avoid solutions and agreements of a bilateral nature, and adopt a solution at the national level for the problem of Darfur and the problems of all peripheral states, especially the problem of land tenure. 
2- A comprehensive national peace conference that includes all parties to the crisis, representatives in the central government in Sudan, armed movements, IDPs in camps, Darfurian refugees, traditional civil administration, tribal leaders and Darfurian refugees around the world in addition to the international and African community, academicians interested of Sudanese universities and everyone who is invited by the organizer.

3- Establishing a land commission, whose tasks include developing the land law, removing disputes, and resolving the issue of land tenure, at both the national and state levels, which are finally included in the constitution.

4- Resettlement of IDPs wishing to return to their lands from which they were expelled, compensation and basic services.

5- To give the utmost importance to the issue of evacuating the new settlers from the lands they seized and returning them to their homelands

6- Assigning academic specialists in various specializations to prepare working papers for the National Peace Conference, especially those related to the issue of land tenure and Hawakir, and setting up workshops and preparatory seminars to discuss and develop these papers before submitting them to the conference.

\section{REFERENCES}

[1] Muhammad Al-Sobh: The concept of the tribe in the third global theory, second edition, Cairo, 1990, p. 28

[2] Eric Reeves, Author, Maya Baca, research and editing, Changing Demography, Violent Expropriation and Destruction of Farmlands in Darfur, Nov 2014-Nov 2015, report presented to UN.

[3] Ali Ahmad Haqqar: The Political Dimension of Tribal Conflict in Darfur, published MA thesis, Omdurman Islamic University, Sudan Press Printing Company, 2003, p. 163.

[4] Article 638/1/2, Civil Transactions Act, Ministry of Justice, Khartoum, Sudan, 1984

[5] Atta Al-Mannan and others, Report on Tribal Conflict in Darfur, Workshop on Security Arrangements after the Abuja Agreement, University of Nyala, October 2006.

[6] Darfur Peace Agreement: Chapter Two, Wealth Sharing, Article 17, General Concepts and Principles of Wealth Sharing, Wealth Sharing Principles, Paragraphs 110/111/112, pp. 29/30

[7] Declaration of Principles on the Darfur Conflict, Paragraph 12, Abuja, Nigeria, July, 52005.

[8] Dr. Al-Tijani Mustafa Mohamed Saleh: Causes of Tribal Conflict in Sudan, a scientific paper presented at a symposium (Insights on Tribal Conflicts in Sudan), Institute of African and Asian Studies, University of Khartoum, 1998, p. 13.

[9] Dr. Mubarak Al-Sharif: Land ownership and Hawakir in Dar Four, paper presented for the Peace building Workshop, Center for Western Sudan Studies, Nyala, 2005, p. 6. http://www.hrw.org/ar/report/2004/05/06 1255586 .

[10] Interim Constitutional Document, Peace Issues, Chapter Fifteen, Article 68, G- Land and Hawakir issues.Khartoum, 17/08/2019.

[11] Muhammad Ibrahim Abu Saleem: The Fur and the Earth (ownership documents), the pamphlet (10), Institute of African and Asian Studies, University of Khartoum, 1975, p. 53.

[12] Naoum Choucair: Geography and History of Sudan, Part One, Beirut, 1967, p. 472.

[13] Radio Dabanga, Poll of IDPs' Views on Voluntary Return, According to the Doha Agreement for Peace in Darfur: It broadcasts news from the Netherlands in Arabic, specializing in news of the conflict in Darfur, September 30, 2015, 09:45

[14] Section 188/190, Article 34, Darfur Peace Document, Doha, Qatar, 2011.

[15] Security Council, Sixty-third year, Session 5905 Thursday, 5 June 2008, 10 am New York.

[16] Sudan Peace Agreement, Security Arrangements, Paragraph 9.12.1 Juba, South Sudan, Oct 3, 2020

[17] The Sudanese Comprehensive Peace Agreement, Chapter Three, Item Two (Land Ownership and Natural Resources), pp. 54-57.

[18] Youssef Tekneh: Report on Tribal Conflict in Darfur, working paper presented at the Conference on Security and Peaceful Coexistence in Darfur, 1997, p. 46.

[19] (Darfuri-Darfuri) dialogue The issue of land and Natural Resources, stability and development in Darfur in paragraph 483 / b / p. 101. Land, water and natural resources and the location and organization of Bedouin roads, El-Fasher, 2016. 
[20] Muhammad Omar Bashir: History of the National Movement in Sudan, The Historical Roots of Modern Sudan, Second Edition, Dar Al-Jeel, Beirut, Lebanon, 1987..

[21] Anwar Yousif \&Others, Socio-Psychological Impact of the Darfur War on Women and Children, MiddleEast Journal of Scientific Research 19 (5): 697-701, 2014, ISSN 1990-9233, (C) IDOSI Publications, 2014, DOI: 10.5829/idosi.mejsr.2014.19.5.21016.

[22] Interview held by Human Rights Watch with a person named Faisal, an old man, Tonfoka village, Dar Masalit, early 2004, report: Darfur destroyed, Genocide committed by the government and militia forces in western Sudan, Volume 16 A, May 2004.

[23] Interview held by Human Rights Watch with a person named Hassan, a 22 years old farmer, Orum village, early 2004, report: Darfur destroyed, Genocide committed by the government and militia forces in western Sudan, Volume 16 A, May 2004.

[24] Interview held by Human Rights Watch, with a person named Faisal, an elderly farmer, The City of ElGeenaina, early 2004, report: Darfur destroyed, Genocide committed by the government and militia forces in western Sudan, Volume 16 A, May 2004.

\section{AUTHOR'S BIOGRAPHY}

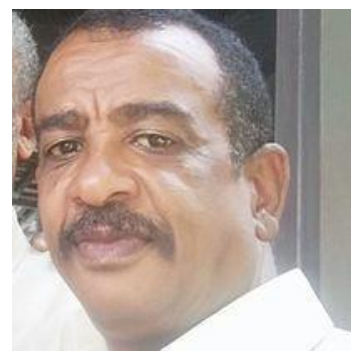

Dr. Anwar Yousif Ataelmanan Mohamed ,/ BA in Economics and Rural Development - University of Gezira - Wad Madani - Sudan 1989 / M.Sc. of Rural and Urban Planning - a joint program between the University of Saxion/ the Netherlands and the University of Greenwich / UK 2000 / PhD in Development Sociology - University of Neelain - khartoum - Sudan.

Citation: Dr. Anwar Yousif Ataelmanan Mohamed. "Janjaweed, New Settlers and the Land Tenure: Do They Constitute an Obstacle to Peace in Sudan?” International Journal of History and Cultural Studies (IJHCS). vol 7, no. 1, 2021, pp. 1-15. doi: DOI: https://doi.org/ 10.20431/2454-7654.0701001.

Copyright: (C) 2021 Authors. This is an open-access article distributed under the terms of the Creative Commons Attribution License, which permits unrestricted use, distribution, and reproduction in any medium, provided the original author and source are credited. 